\section{ANTARCTIC ENVIRONMENT}

\section{Not the}

\section{'dirty man'}

\section{Cambridge}

DAvid Walton has perhaps the most sensitive job at BAS. In addition to heading the Terrestrial and Freshwater Life Sciences Division, he must ensure that the British scientific presence in Antarctica causes the minimum possible damage to the fragile Antarctic environment.

Antarctic environmental protection is a hot political topic, overshadowed by strong feelings about the eventual possibility of oil and minerals exploration. The Antarctic Treaty nations last year met in Vina del Mar, Chile, to begin work on a protocol to protect the Antarctic environment (see Nature 348, $269 ; 29$ November 1990 \& 348, 570; 13 December 1990). But much work remains to be done, starting at a meeting in Madrid next month. Walton and his staff will have a key role providing scientific support for the British delegation to Madrid.

Walton believes the efforts BAS has made to protect the Antarctic environment have not been given the recognition they deserve. Environmentalist pressure groups have labelled Britain 'the dirty man of Europe', and the assumption is that the tag also applies to the British bases in Antarctica. But "when people turn round to me and say 'you're desecrating the Antarctic', I feel they haven't done their homework", says Walton.

Britain has been monitoring the environmental impact of its bases for longer than any other Antarctic nation. A programme to monitor vegetation changes around the Signy base began in 1964, and the accumulation of heavy metals in lichens has been studied at Rothera since 1976.

Before starting work on a new airstrip at the Rothera base, BAS carried out the firstever Comprehensive Environmental Evaluation (CEE) of the effects of the development. (The Antarctic Treaty nations decided in 1987 that thorough CEEs should be carried out before any major construction work.) BAS concluded that the airstrip would cause minimal damage outside the small area already affected by the presence of the Rothera base. Environmental monitoring around the airstrip will continue for the next few years, to compare the true environmental impact with BAS's predictions. The results will be published, Walton says.

During the airstrip's construction, which began in January 1990 and is now reaching completion, BAS invited Cassandra Phillips, from the World Wide Fund for Nature, to check that the work was progressing as the CEE had promised. Walton puts a high value on a constructive dialogue with enviromentalist groups, but relations occasionally become strained. Greenpeace, for example, is opposed to the construction of new airstrips in Antarctica, so was not placated by the Rothera CEE.

P.A.

\title{
A steady expansion
}

\section{Cambridge}

APART from bringing a welcome increase in BAS's annual budget, the resurgence of British Antarctic science sparked by the 1983 Bondi plan (see previous page) has seen an impressive programme of capital investment.

BAS scientists will this June take delivery of the new jewel in their crown, the £35million research ship James Clark Ross, ordered to replace the ageing John Biscoe. The James Clark Ross will open up a whole range of new research possibilities to BAS's geoscientists and biologists, who will take turns to man the ship in alternate Antarctic summer field seasons.

The geoscientists get the first bite at the cherry, and set sail for Antarctica in September. Peter Barker, head of BAS's Geophysics Division, says that his team has often been forced to rely on research vessels lacking icestrengthening, such as the Charles Darwin.

On board the ice-worthy James Clark Ross, BAS geoscientists will be able to sail further south than before, and take 30metre-deep sediment cores from the sea bed off the Antarctic Peninsula continental shelf. These will provide valuable information about Antarctica's glacial history.

The new ship can also carry a larger supply of compressed air than other British research vessels. This generates the seismic signals used by geophysicists to survey the sea bed. "In the past, we haven't been able to make big enough bangs", says Barker.

Barker hopes that BAS can find a further $£ 1$ million to fit the James Clark Ross with swath bathymetry equipment, which can produce topographical maps of the sea bed by echo-sounding, surveying across a band twice as wide as the sea depth at a single pass. With an accurate map of the sea bed's topography, BAS scientists would be able to deploy delicate ship-towed instruments, without the risking their loss or damage.

BAS marine biologists are also enthusias-

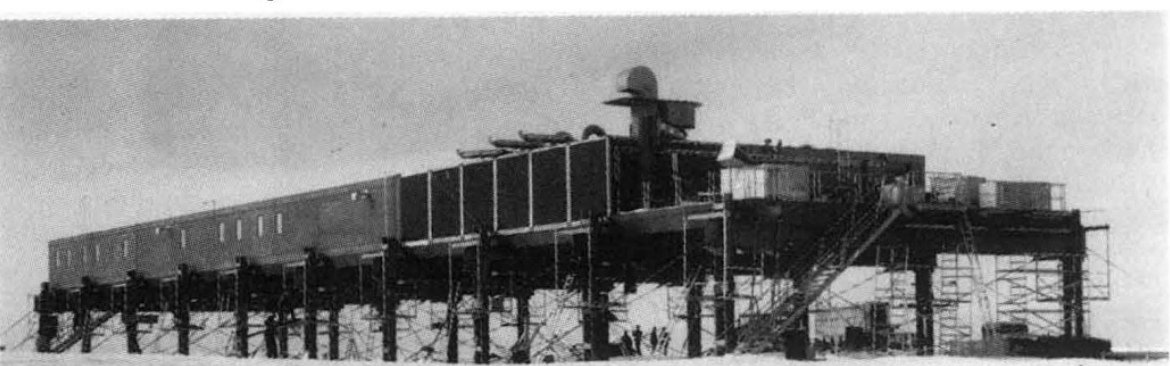

tic about the new ship. The James Clark Ross is equipped with commercial-scale trawling nets, many times larger than those carried by the John Biscoe. BAS biologists will use these to sample Antarctic fish and squid populations, to extend their long- term study of the Southern Ocean ecosystem.

The new ship is the most expensive recent addition to Britain's Antarctic research infrastructure, but is only part of a wider programme of improvement. The new crushed rock airstrip at Rothera base should become operational later this year and the southernmost British base, at Halley, has been rebuilt and is now being furnished. BAS is also applying to the government for funds to rebuild

The new Halley base, which should become fully operational during 1992, is a remarkable structure, consisting of one large accommodation block and two smaller blocks housing the laboratories, all built on platforms raised up from the ice. Halley is sited on the floating Brunt Ice Shelf and moves 700 metres away from the Antarctic coast each year. More significantly, snowfall causes the ice surface to rise by about 1 metre a year, engulfing any doorway built at the surface.

The previous four bases at Halley were all built buried in the ice sheet, and people had to enter and leave through shafts to the surface. But a buried base is difficult to repair and maintain. The new Halley platforms can be jacked up manually each year to keep above the rising ice, a feature that will extend their life by five to ten years. a new aircraft to supply its fieldworkers. A secondhand de Havilland Dash-7 is now in Canada, being fitted with the wheel-ski undercarriage that will enable it to land on the ice. The aircraft should come into operation in the 1993-94 field season, with more than twice the range of BAS's four small de Havilland Twin-Otter aircraft.

P.A. the Signy base.

BAS is also spending $£ 5$ million to provide 